\title{
Neutron Induced Fission Track Estimation of Uranium Concentration and Its Associated Health Hazards in Drinking Water of the Faisalabad Industrial City
}

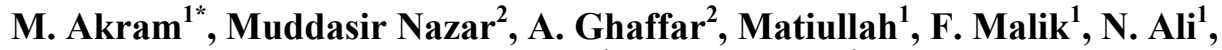 \\ S. A. Mujahid ${ }^{1}$, M. U. Rajput ${ }^{1}$ \\ ${ }^{1}$ Physics Division, PINSTECH, Islamabad, Pakistan \\ ${ }^{2}$ Department of Physics, University of Agriculture, Faisalabad, Pakistan \\ Email: ${ }^{*}$ akram1662@gmail.com
}

Received August 9, 2012; revised January 16, 2013; accepted February 3, 2013

Copyright (C) 2013 M. Akram et al. This is an open access article distributed under the Creative Commons Attribution License, which permits unrestricted use, distribution, and reproduction in any medium, provided the original work is properly cited.

\begin{abstract}
Drinking water plays a major role regarding quality of human life because polluted water is the main cause of many types of diseases. Besides other pollutants, high concentration of uranium above a certain level in drinking water is also hazardous. As water and food are the main sources of uranium intake, it is absolutely imperative that their level of concentrations is monitored regularly for safety of the general public. In this regard, trace amount of uranium in drinking water samples collected from different locations of Faisalabad city has been carried out using Neutron Induced Fission Track Technique. The water samples along with the standard of known uranium concentration were poured and dried over Lexan track detectors and then irradiated with thermal neutrons in Reactor. After etching, the tracks produced in the detectors as a result of ${ }^{235} \mathrm{U}$ (n, f) reaction were counted under an optical microscope. The uranium concentration was determined by counting and comparing the observed fission track density in the samples and the standard. The observed uranium concentration in the studied water samples varied from $(1.04 \pm 0.30) \mu \mathrm{g} \cdot \mathrm{L}^{-1}$ to $(21.08 \pm 2.95) \mu \mathrm{g} \cdot \mathrm{L}^{-1}$ with an average value of $(7.39 \pm 1.30) \mu \mathrm{g} \cdot \mathrm{L}^{-1}$ and is found to be within safe limits as far as uranium related health hazards are concerned.
\end{abstract}

Keywords: Drinking Water; Uranium; Fission Tracks; Etching; Health Hazard

\section{Introduction}

Uranium is a radioactive element found in nature discovered by Martin Heinrich Klaprothe in 1789. It has three isotopes namely, ${ }^{234} \mathrm{U}(0.0055 \%),{ }^{235} \mathrm{U}(0.720 \%)$ and ${ }^{238} \mathrm{U}$ $(99.2745 \%)$, all of which are long-lived alpha emitters. It can be present in almost all soil, minerals, rocks, sand, plants food and water in the varying proportions due to their natural occurrences or introduced by the activities of human [1]. The average uranium concentration in the earth's crust has been reported to be $4 \mathrm{ppm}$ by weight while in the phosphate rocks its value may be as high as 120 ppm by weight [2].

Uranium and its salts are highly toxic and may exist in the $+2,+3,+4,+5$ or +6 valence states. The most prevalent are the hexavalent and tetravalent states states [1]. The hexavalent state is particularly important in water and other food items because almost all tetravalent com-

"Corresponding author. pounds are insoluble. Besides other pollutants, water also contains trace amount of uranium which may find its way right to the human food [3]. Besides being radioactive, uranium is highly chemically toxic thereby resulting in health hazards if exceeds certain limits.

Uranium may enter into drinking water or food chain from naturally-occurring deposits by leaching processes or as a result of human activity, such as mining and milling [4]. After it enters into the human body through ingestion, most of the ingested uranium is eliminated from the body. However, a small amount is absorbed and carried through the bloodstream into the kidneys. The ingestion of high values of uranium in drinking water and foodstuffs therefore damages kidneys, preventing normal elimination of urea and other waste products, resulting in renal dysfunction [1]. Therefore, it may be hazardous if inhaled or ingested in excessive quantities [1,5-9]. Water having uranium concentration above the proposed Maxi- 
mum Acceptable Concentration ranges of $9-30 \mu \mathrm{g} \cdot \mathrm{L}^{-1}$ is not safe for drinking purposes as it leads to harmful health effects in humans [10-13]. Studies show that elevated levels of uranium in drinking water can increase a person's risk of kidney damage. The increased kidney damage/cancer risk depends on the concentration of radioactivity found in the drinking water, the amount of water consumed on a daily basis, and the duration one has consumed the water.
Uranium has been extensively studied in soil, minerals, rocks, sand, plants, food and water [1,3,9,14-20]. Due to industrialization, most of the drinking water sources have been polluted in industrial cities of Pakistan [21-24]. Hence, the assessment of health risk due to the high concentration of uranium in water is most important. In this context, an industrial city of the Faisalabad city was chosen. Drinking water samples were collected from different locations of the city (see, Figure 1) and ura-

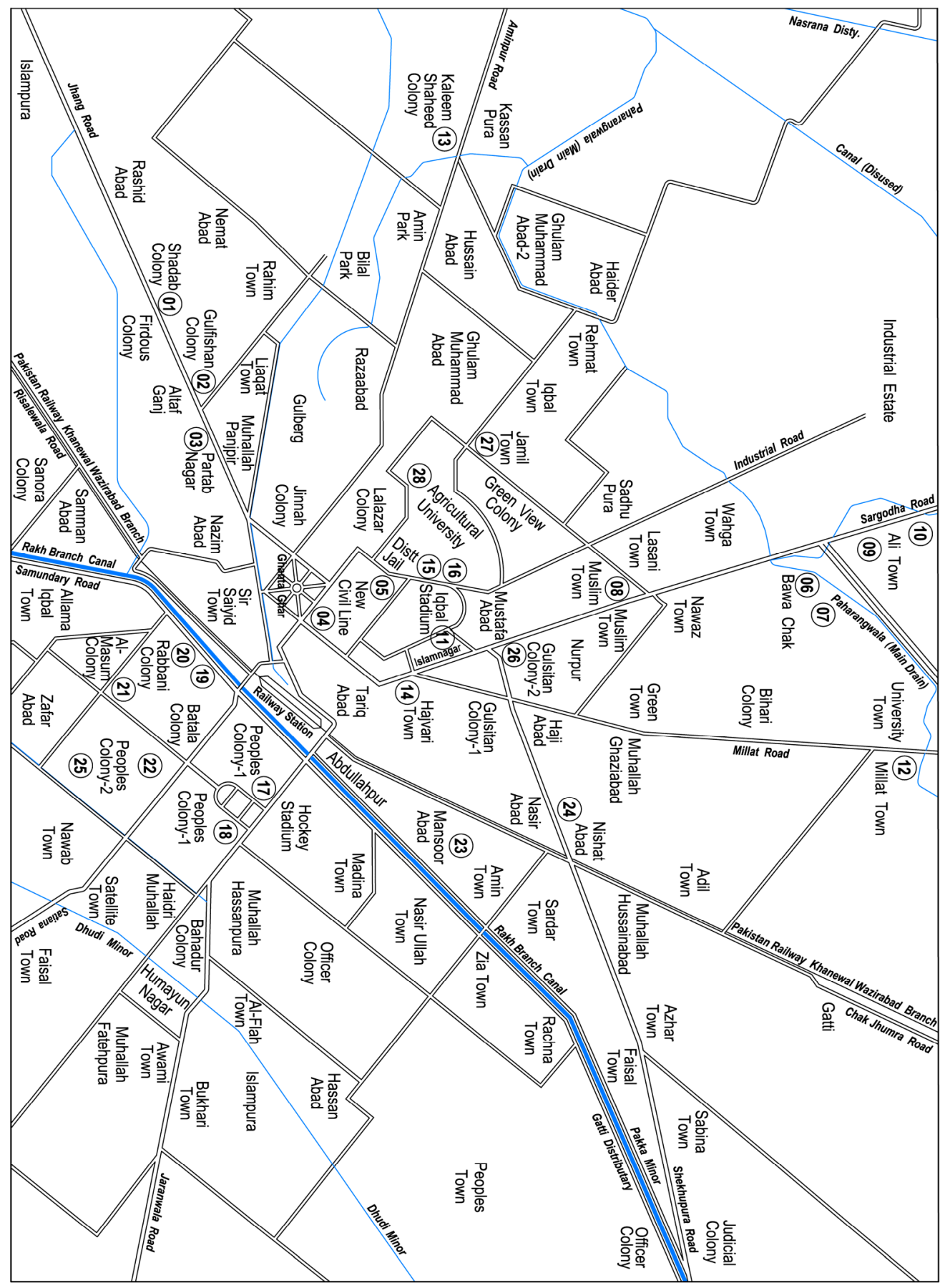

Figure 1. Map of the Faisalabad city showing location of sampling. 
nium concentration in these samples were estimated using Neutron Induced Fission Track Technique [2,3,14,15, $18,25,26]$. Main objective of this investigation was to save the people from harmful effect of uranium if any because the people of city use this water for drinking and other domestic purposes.

The Neutron Induced Fission Track Technique has been applied for determination of uranium in solid and liquid samples by many workers $[3,14,15,18,27,28]$. This technique is based on using ${ }^{235} \mathrm{U}(\mathrm{n}, \mathrm{f})$ reaction whose fission cross-section is 4.2 barns for thermal neutron. The basic principle of the technique is that in natural uranium, only ${ }^{235} \mathrm{U}$ is fissionable by thermal neutrons. Hence, if a drop of unknown liquid sample and standard of known uranium, dried on nuclear track detectors, irradiate simultaneously by the same integrated flux of thermal neutrons in the reactor, the uranium content in the unknown sample is calculated after chemical etching by counting and comparing the total number of observed fission tracks produced in the detectors due to uranium in the samples and standard as a result of $(\mathrm{n}, \mathrm{f})$ nuclear reaction in the reactor (Figure 2).

\section{Materials and Methods}

In this study, twenty eight water samples of different sources were collected from different locations of the Faisalabad city in $500 \mathrm{ml}$ plastic bottles as shown in Table 1. From each bottle $250 \mathrm{ml}$ water was taken into a conical flask and was heated on a hot plate until $5 \mathrm{ml}$ concentrated solution was left behind. All the water samples were concentrated one by one and kept separately in glass bottles. Standard solution of uranium was also prepared from uranium oxide (having certified composition of $99.94 \% \mathrm{U}_{3} \mathrm{O}_{8}$ ). After concentration, most widely used plastic detector material for recording fission particles namely Lexan $\left(\mathrm{C}_{16} \mathrm{H}_{18} \mathrm{O}_{3}\right)$ with trade name of Lexan ${ }^{\circledR}$

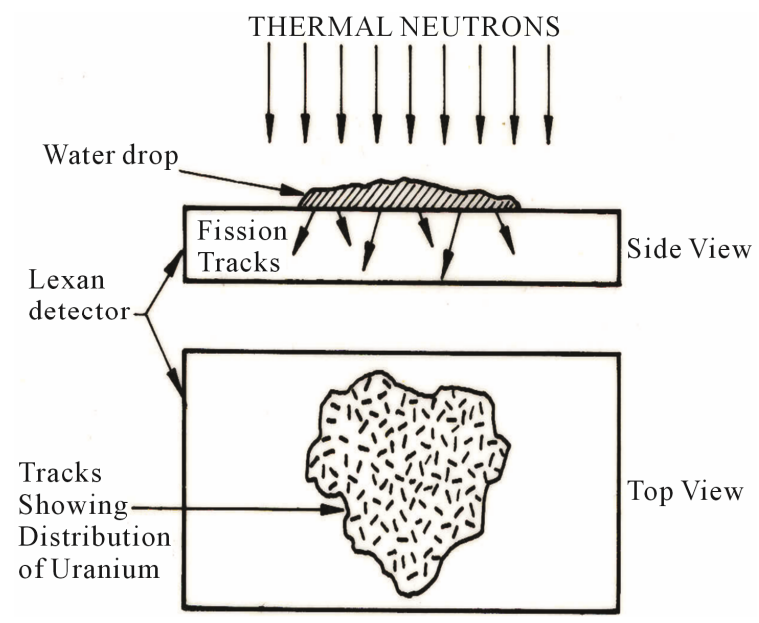

Figure 2. Schematic representation of the neutron induced fission track analysis technique.
Table 1. Results of uranium contents in water samples from different localities of Faisalabad city, Pakistan $\left(\mu \mathrm{g} \cdot \mathrm{L}^{-1}\right)$.

\begin{tabular}{|c|c|c|c|c|}
\hline $\begin{array}{l}\text { Sample } \\
\text { No. }\end{array}$ & Sampling Site & $\begin{array}{l}\text { Source } \\
\text { of Water }\end{array}$ & $\begin{array}{c}\text { Track } \\
\text { Density } \\
\left(\# / \mathrm{cm}^{2}\right) \times 10^{3}\end{array}$ & $\begin{array}{c}\text { U Conc. } \pm \\
1 \sigma^{*} \\
\left(\mu \mathrm{g} \cdot \mathrm{L}^{-1}\right) \\
\end{array}$ \\
\hline F-1 & Shadab Colony & Hand Pump & $90.15 \pm 1.87$ & $19.53 \pm 2.81$ \\
\hline $\mathrm{F}-2$ & Gulfishan Colony & Hand Pump & $35.70 \pm 1.23$ & $7.74 \pm 1.44$ \\
\hline F-3 & Partab Nagar & Hand Pump & $74.41 \pm 1.74$ & $16.13 \pm 2.47$ \\
\hline $\mathrm{F}-4$ & Civil Lines & Hand Pump & $42.51 \pm 1.40$ & $9.21 \pm 1.67$ \\
\hline F-5 & Civil Lines & Filteration Plant & t $4.78 \pm 0.40$ & $1.04 \pm 0.30$ \\
\hline F-6 & $\begin{array}{c}\text { Office, Motorway } \\
\text { City Sargodha Road. }\end{array}$ & Hand Pump & $21.55 \pm 0.95$ & $4.67 \pm 0.98$ \\
\hline F-7 & $\begin{array}{l}\text { Plot } 69, \text { Motorway } \\
\text { City Sargodha Road }\end{array}$ & Hand Pump & $18.90 \pm 0.80$ & $4.10 \pm 0.84$ \\
\hline F-8 & Muslim Town-3 & Hand Pump & $40.39 \pm 1.27$ & $8.75 \pm 1.55$ \\
\hline F-9 & Ali Town & Hand Pump & $41.38 \pm 1.35$ & $8.97 \pm 1.62$ \\
\hline F-10 & Ali Town & Tube Well & $58.43 \pm 1.66$ & $12.66 \pm 2.14$ \\
\hline F-11 & Islam Nagar & Tube Well & $10.36 \pm 0.65$ & $2.24 \pm 0.56$ \\
\hline F-12 & Millat Town & Tube Well & $6.67 \pm 0.51$ & $1.44 \pm 0.40$ \\
\hline $\mathrm{F}-13$ & $\begin{array}{c}\text { Kaleem Shaheed } \\
\text { Colony }\end{array}$ & Hand Pump & $11.73 \pm 0.71$ & $2.54 \pm 0.62$ \\
\hline F-14 & Hajwari Town & Hand Pump & $47.56 \pm 1.41$ & $10.31 \pm 1.77$ \\
\hline F-15 & Bilal Colony & Hand Pump & $24.76 \pm 0.97$ & $5.36 \pm 1.06$ \\
\hline F-16 & Bilal Colony & Tube Well & $17.27 \pm 0.85$ & $3.74 \pm 0.83$ \\
\hline F-17 & Peoples Colony-1 & Tube Well & $12.09 \pm 0.77$ & $2.62 \pm 0.66$ \\
\hline F-18 & Peoples Colony-1 & Hand Pump & $97.28 \pm 1.902$ & $21.08 \pm 2.95$ \\
\hline F-19 & Rabbani Colony & Tube well & $8.44 \pm 0.60$ & $1.83 \pm 0.49$ \\
\hline $\mathrm{F}-20$ & Rabbani Colony & Hand Pump & $61.38 \pm 1.54$ & $13.30 \pm 2.11$ \\
\hline $\mathrm{F}-21$ & Rabbani Colony & Tube Well & $23.92 \pm 0.89$ & $5.18 \pm 1.00$ \\
\hline $\mathrm{F}-22$ & Peoples Colony-2 & Tube Well & $24.85 \pm 0.89$ & $5.38 \pm 1.02$ \\
\hline $\mathrm{F}-23$ & Mansoor Abad & Hand Pump & $51.14 \pm 1.36$ & $11.08 \pm 1.81$ \\
\hline $\mathrm{F}-24$ & Nishat Abad & Hand Pump & $25.45 \pm 1.08$ & $5.52 \pm 1.14$ \\
\hline$F-25$ & $\begin{array}{l}\text { Peoples Colony } \\
\text { No-2 }\end{array}$ & Tube Well & $22.58 \pm 1.06$ & $4.89 \pm 1.06$ \\
\hline F-26 & $\begin{array}{c}\text { Gulistan Colony } \\
\text { No-2 }\end{array}$ & Tube Well & $12.26 \pm 0.65$ & $2.66 \pm 0.61$ \\
\hline $\mathrm{F}-27$ & $\begin{array}{l}\text { Jamil Town, } \\
\text { G.M. Abad }\end{array}$ & Tube Well & $8.02 \pm 0.61$ & $1.74 \pm 0.48$ \\
\hline F-28 & Jinnah Hall, UAF & Hand Pump & $60.39 \pm 1.60$ & $13.09 \pm 2.13$ \\
\hline \multicolumn{3}{|c|}{ Average Concentration } & $7.39 \pm 1.30 \mu$ & $\mathrm{g} \cdot \mathrm{L}^{-1}$ \\
\hline \multicolumn{3}{|c|}{ Minimum Concentration } & $1.04 \pm 0.30 \mu$ & $\mu g \cdot L^{-1}$ \\
\hline \multicolumn{3}{|c|}{ Maximum Concentration } & $21.08 \pm 2.95 \mu$ & $\mathrm{g} \cdot \mathrm{L}^{-1}$ \\
\hline
\end{tabular}

${ }^{*}$ Statistical counting error $=1 \mathrm{SD}$. 
(supplied by General Electric Company, USA) having $125 \mu \mathrm{m}$ thickness was cut into small pieces each of size $1 \mathrm{~cm} \times 1 \mathrm{~cm}$. A drop of $0.05 \mathrm{ml}$ of concentrated solution of each water sample and standard were taken separately with the help of an accurately calibrated micropipette and poured over the surfaces of the sensitive face of the Lexan detectors. After drying the drop over the surfaces of the Lexan ${ }^{\circledR}$ detectors, the solid residue left behind on each detector was then covered with another Lexan detector of the same size so as to sandwich the residues. The procedure was repeated for every sample.

The Lexan ${ }^{\circledR}$ detector assemblies (Figure 3) along with one blank Lexan ${ }^{\circledR}$ detector (for background) were irradiated simultaneously with thermal neutrons in the Pakistan Research Reactor-I (PARR-1), PINSTECH, Islamabad, with thermal neutrons for 100 seconds under a thermal neutron flux of the order of $10^{15}$ neutrons $\mathrm{cm}^{-2} \cdot \mathrm{s}^{-1}$. After irradiation, the detectors were etched in $6.5 \mathrm{M}$ $\mathrm{NaOH}$ solution for 45 minutes at $50^{\circ} \mathrm{C} \pm 1{ }^{\circ} \mathrm{C}$ in etching bath. After etching, the fission tracks produced in the water drop area of all the etched detectors due to uranium were counted using Zeiss optical microscope at a magnification of $400 \times$.

In order to determine uranium concentration in water, the observed track densities in water samples were related to the track density obtained in the standard of known uranium concentration. Because both the sample and the standard were irradiated and etched under similar conditions, the uranium concentration relative to a $10^{4}$ $\mu \mathrm{g} \cdot \mathrm{L}^{-1}$ standard uranium solution was calculated by the relation $[3,14,15,18,28]$ :

$$
C_{U X}=C_{U S}\left[\left(\frac{\rho_{X}}{\rho_{S}}\right)\left(\frac{I_{S}}{I_{X}}\right)\left(\frac{R_{S}}{R_{X}}\right)\right]
$$

where the subscripts $x$ and $s$ stand for unknown and standard sample respectively. In the above relation, $C$ is the uranium concentration, $\rho$ is the track density, $I$ is the isotopic abundance ratio of ${ }^{235} \mathrm{U}$ and ${ }^{238} \mathrm{U}$ and $R$ is the range of fission fragments in the detector. The quantities $R_{S} / R_{X}$ and $I_{S} / I_{X}$ are correction factors applied when the composition of the sample and the standard are different.

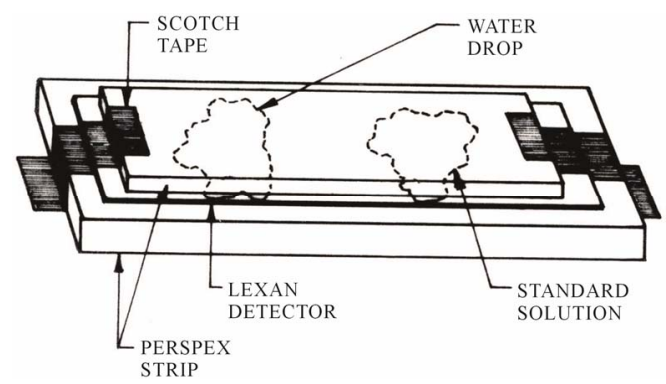

Figure 3. Experimental arrangement of the unknown and known sample assembly for neutron irradiation in the reactor.
The values of $R_{S} / R_{X}$ and $I_{S} / I_{X}$ were assumed to be unity in the present study because the same isotopic abundance ratio and range of fission fragments in the standard and unknown sample having almost same composition.

\section{Results and Discussion}

As mentioned earlier, the present study deals with determination of the uranium concentration in drinking water samples using Lexan based neutron Induced Fission Track Technique. The results of measured uranium concentration in each sample along with their sampling sites and sources of water samples collected from different locations of Faisalabad city area are shown in Table 1. As the water samples were 50 times concentrated, therefore, the uranium concentrations in the last column of the Table 1 are divided by 50 .

As may be seen in Table 1, the measured uranium concentration in the studied samples ranges from $1.04 \pm$ $0.30 \mu \mathrm{g} \cdot \mathrm{L}^{-1}$ to $21.08 \pm 2.95 \mu \mathrm{g} \cdot \mathrm{L}^{-1}$ with an average value of $7.39 \pm 1.30 \mu \mathrm{g} \cdot \mathrm{L}^{-1}$. Uranium concentration in the samples is seen to vary from tube well to tube well, hand pump to hand pump and place to place showing slight variation in the water of the studied area.

Higher uranium concentration were observed in the water sample collected from Peoples colony -1 (21.08 $\left.\mu \mathrm{gL}^{-1}\right)$, Shadab Colony $\left(19.53 \mu \mathrm{g} \cdot \mathrm{L}^{-1}\right)$ and Partab Nagar $\left(16.13 \mu \mathrm{g} \cdot \mathrm{L}^{-1}\right)$, respectively. Although these concentrations were towards higher side but were within the safe limits of $9-30 \mu \mathrm{g} \cdot \mathrm{L}^{-1}$ set by different health agencies of the world $[10-13,29,30]$. Uranium concentrations in groundwater depend on the mineralogical, geochemical and chemical composition of the soil rock and water. A recent survey found that drinking waters depends on the local geology of the rock and soil, having uranium contents dangerous for consumer health [31]. Although this area of the city was well established having good facilities and infrastructure, the high uranium concentration in these hand pump water samples might be due to the presence of naturally occurring underground uraniumbearing local geological rocks/soil of the area.

Minimum uranium concentration of $1.04 \mu \mathrm{g} \cdot \mathrm{L}^{-1}$ and $1.44 \mu \mathrm{g} \cdot \mathrm{L}^{-1}$ were found in the water sample collected from the filtration plant of Civil Lines and tube well of the Millat Town, respectively. The people of the area had facility of filtration plant which might be the reason of low value of uranium concentration in the water sample taken from civil lines area. This water was taken from filtration plant (tube well having more depth) which was naturally filtered as well as filtered in the filtration plant to minimize the contaminations. On the other hand, water from tube well of the Millat Town contained lower concentration. This may be due to the fact this water was taken from more depth of tube well. Therefore, it was more safe as for as contaminations are concerned. So 
water of both these areas was found to be more clean and safe for public use as for as uranium related hazards are concerned.

During the current study, it was found that about $71 \%$ water samples have uranium concentration levels below $10 \mu \mathrm{g} \cdot \mathrm{L}^{-1}$, while the percentage of the samples containing uranium concentration in the range $10-21 \mu \mathrm{g} \cdot \mathrm{L}^{-1}$ was only about $29 \%$.

The main rocks exposed in the geological formation of the area are sandstone, siltstone shale, conglomerate etc. These rocks generally do not contain high uranium content to pose any health threat but some contribution from these local rocks and soils is expected due to the leaching and weathering processes of the rocks which contain uranium. Contribution from industrial wastes and anthropogenic discharges from sources such as oil and coal power generation plants, wood burning, glass product manufacturing, bleaching agent in detergents, bleaching of clothes, leaching of treated wood/paper, consumer products (e.g., cosmetics, medicines, insecticides), pesticides, copper smelters, fertilizer etc. into the nearby flowing streams might be the other cause of uranium concentration in the underground water aquifer.

Table 2 shows observed concentration of uranium in water samples from the hand pumps of the Faisalabad city which ranges from $2.54-21.08 \mu \mathrm{g} \cdot \mathrm{L}^{-1}$ with an average of $10.09 \mu \mathrm{g} \cdot \mathrm{L}^{-1}$. Refering back to Table 2, the uranium concentration in tube well water ranged from 1.44 $\mu \mathrm{g} \cdot \mathrm{L}^{-1}$ to $12.66 \mu \mathrm{g} \cdot \mathrm{L}^{-1}$ with an average value of 4.03 $\mu \mathrm{g} \cdot \mathrm{L}^{-1}$. Inter comparing hand pumps, tube wells and filtration plants data, it was found that average concentration of uranium in hand pump was 9.7 and 3.9 times greater than filtration plants and tube well water samples respectively.

The present data have also been compared with uranium concentration in water samples reported for other countries of the world. The reported uranium concentrations ranged from $1.4-7.4$ in hot springs water in India [25]. The uranium concentration in the range of 0.015 $973.0 \mu \mathrm{g} \cdot \mathrm{L}^{-1}$ were reported in the domestic water supplies of USA [32]. The uranium concentration in the range of $0.015-973.0 \mu \mathrm{g} \cdot \mathrm{L}^{-1}$ were reported in the domestic water supplies of USA [33]. In a 1980-1981 sur-

Table 2. The range of uranium contents and their average value in water samples from different sources of water.

\begin{tabular}{cccc}
\hline Sr. No. & Source & $\begin{array}{c}\text { Range of U-Content } \\
\mu \mathrm{g} \cdot \mathrm{L}^{-1}\end{array}$ & $\begin{array}{c}\text { Average Uranium } \\
\text { Concentration } \mu \mathrm{g} \cdot \mathrm{L}^{-1}\end{array}$ \\
\hline 1. & Hand pump & $2.54-21.08$ & $10.09\left(16^{*}\right)$ \\
2. & Tube well & $1.44-12.66$ & $4.03\left(11^{*}\right)$ \\
3. & Filtration plant & 1.04 & $1.04\left(1^{*}\right)$ \\
\hline
\end{tabular}

"The figures within parentheses indicate the number of samples. vey of 13 selected sites in south-central British Columbia, the mean uranium concentration in 519 water samples of surface and ground water (some treated) has been reported to be $4.06 \mu \mathrm{g} \cdot \mathrm{L}^{-1}$. The reported values of uranium concentration in various community water supplies of USA are greater than permissible limit of $30 \mu \mathrm{g} \cdot \mathrm{L}^{-1}$. In another study reported for USA, an average concentration of $3 \mu \mathrm{g} \cdot \mathrm{L}^{-1}$ uranium in drinking groundwater has been reported [1]. Uranium concentrations up to 700 $\mu \mathrm{g} \cdot \mathrm{L}^{-1}$ have been found in private groundwater supplies of Canada [34]. The mean and median levels of naturally derived uranium in groundwater of 287 wells sampled in the southeastern Manitoba (1982-1984) were $58.3 \mu \mathrm{g} \cdot \mathrm{L}^{-1}$ and $10 \mu \mathrm{g} \cdot \mathrm{L}^{-1}$, respectively, with a maximum value of $2020 \mu \mathrm{g} \cdot \mathrm{L}^{-1}$ [35]. The uranium concentrations varied from $0.67-20.26 \mu \mathrm{g} \cdot \mathrm{L}^{-1}$ in domestic and surface water samples from India [36]. Uranium concentration in water samples using fission-track technique from the Muzaffarabad area, Azad Kashmir varied from $0.03 \pm 0.01$ $\mu \mathrm{g} \cdot \mathrm{L}^{-1}$ to $6.67 \pm 0.14 \mu \mathrm{g} \cdot \mathrm{L}^{-1}$ with an average of $1.36 \pm$ $0.05 \mu \mathrm{g} \cdot \mathrm{L}^{-1}$ [3]. The concentration of uranium in drinking water samples from different states of India was found $0.1 \pm-19.6 \mu \mathrm{g} \cdot \mathrm{L}^{-1}$ by laser-induced fluorimetry [36]. An association between uranium in drinking water from drilled wells and of kidney function was studied The uranium content of well water samples was measured in the range of $<0.20-470 \mu \mathrm{g} \cdot \mathrm{L}^{-1}$ having a median value of $6.7 \mu \mathrm{g} \cdot \mathrm{L}^{-1}$, while uranium levels in all samples of municipal water were below $0.2 \mu \mathrm{g} \cdot \mathrm{L}^{-1}$ [19]. Typical concentration of $U$ in uncontaminated groundwater in many parts of the world is below $1.0 \mu \mathrm{g} \cdot \mathrm{L}^{-1}$ although values in excess of $1000 \mu \mathrm{g} \cdot \mathrm{L}^{-1}$ water have been reported $[31,37]$. Average uranium concentration in tap water samples from various European countries was found to be $2.2 \mu \mathrm{g} \cdot \mathrm{L}^{-1}$ and values above the WHO guideline (15 $\mu \mathrm{g} \cdot \mathrm{L}^{-1}$ ) were reported from Germany, France, Sweden, and Switzerland [31]. An average uranium content of 2.5 $\mu \mathrm{g} \cdot \mathrm{L}^{-1}$ was found in domestic water samples in US in a study performed by the National Uranium Resource Evaluation (NURE) program [31,38]. This comparison shows that, the range of uranium concentration in drinking water found in this study lies towards the lower side of the ranges, reported for other locations. The results of the study can also be compared with the worldwide guidelines for the uranium concentration in drinking water. The average observed uranium concentrations in the drinking water samples are found lower than the maximum acceptable concentration levels of Australia (20 $\left.\mu \mathrm{g} \cdot \mathrm{L}^{-1} ;[10]\right)$, Canada $\left(20 \mu \mathrm{g} \cdot \mathrm{L}^{-1} ;[12]\right)$, USA $\left(30 \mu \mathrm{g} \cdot \mathrm{L}^{-1}\right.$; [11]), WHO (9 $\left.\mu \mathrm{g} \cdot \mathrm{L}^{-1} ;[13]\right)$. Consequently, the health hazards related to uranium in drinking water were expected to be negligible.

It may be noted here that the average value of $7.39 \pm$ $1.30 \mu \mathrm{g} \cdot \mathrm{L}^{-1}$ in the text as well as in Table 1 means the 
average value of the measured data in this work. It does not mean the real average concentration of uranium in the water in the whole area. It is an easily obtainable figure from a limited number of water samples without taking into account of the water reserve represented by each sample. However, considering health hazard related with ingestion of drinking water having concentration of uranium above recommended level. It is, therefore, desirable that uranium in drinking water samples survey on regional scale should also be monitored to address this issue of public health concern.

By making a measurement relative to the concentration of uranium in standard, many sources of uncertainty are cancelled out and the remaining dominant uncertainty is the statistics of the track counting. The errors ( \pm represents 1 standard deviation) in the track densities were calculated by multiplying track density by $(1 / \mathrm{N})^{1 / 2}$, where $\mathrm{N}$ is the total number of tracks counted in that sample. The tracks of every detector were counted by taking more fields of view to reduce any statistical counting error in the total track density, and uranium concentrations were determined with 1 standard deviation. The systematic error due to the clustering of tracks was small as the numbers of clusters found in this study were negligible. The reliability of the results obtained by this method primarily depends upon the accurate measurements of neutron flux and the number of counted fission tracks. However, the uncertainty due to the first factor is eliminated by comparing track counts for the same flux.

The total uncertainties in the uranium concentration for each unknown were calculated by combining the statistical uncertainties of track number of unknown sample and that of standard sample as well as the uncertainty of uranium concentration of standard sample. The uranium concentrations were determined up to one standard deviation.

In order to obtained a reasonably good statistics of track counts, 30 - 60 fields-of-view were selected randomly on each of the detector surfaces, which was in contact with sample residue at the time of irradiation. In order to obtain accurate results, a blank detector was exposed along with the sample to subtract background track density (track density resulting from fission of uranium present as a constituent of the detector) from the total track densities. However, background tracks contribution due to uranium in the Lexan ${ }^{\circledR}$ detector was found negligible.

The uniformly distributed fission tracks formed due to the dissolved uranium were easily differentiated from the cluster-type fission tracks due to the suspended particles in water. From the results of the samples, it was obvious that the distribution of uranium is uniform except in few cases, where clustering of tracks (fission track stars) appeared within the area containing droplet residue. In ad- dition to the uranium, tracks produced due to thorium may interfere in the uranium determination. However, because of its low concentration in the water and relatively smaller thermal neutron cross section, the contribution of thorium was negligible.

\section{Conclusion}

To conclude, uranium concentration in drinking water of the Faisalabad city vary from $1.04 \pm 0.30$ to $21.08 \pm 2.95$ $\mu \mathrm{g} \cdot \mathrm{L}^{-1}$ with an average value of $7.39 \pm 1.30 \mu \mathrm{g} \cdot \mathrm{L}^{-1}$. The observed uranium concentration in hand pump is $\sim 10$ and 4 times greater than those of filtration plants and tube wells water samples respectively. The deep underground water obtained from tube well is safer for drinking purposes as compared to shallow surface underground water from hand pump while the water from filtration plant was safest as far as uranium related health hazards are concerned. The average observed levels of uranium concentrations in the studied water samples is within the safe limits $\left(9-30 \mu \mathrm{g} \cdot \mathrm{L}^{-1}\right)$ set by different heath agencies of the world. Consequently, the health hazards related to uranium in drinking water in this area are negligible and use of this water for drinking and other purposes may not pose any health risk. However, health hazards related to other toxic and trace elements present in drinking water samples from this area should also be monitored with great care before declaring it free of any health related hazard.

\section{REFERENCES}

[1] C. R. Cothern and W. L. Lappenbusch "Occurrence of Uranium in Drinking in the US," Health Physic, Vol. 45, No. 1, 1983, pp. 89-99. doi:10.1097/00004032-198307000-00009

[2] P. Singh, N. P. S. Rana, A. Azam, A. H. Naqvi and D. S. Srivastava, "Levels of Uranium in Waters from Some Indian Cities Determined by Fission Track Analysis," Radiation Measurements, Vol. 26, No. 5, 1996, pp. 683-687. doi:10.1016/S1350-4487(97)82882-X

[3] M. Akram, N. U. Khattak, A. A. Qureshi, A. Iqbal, M. Shafique, M. Tufail and I. E. Qureshi, "Fission Track Estimation of Uranium Concentrations in Drinking Water from Azad Kashmir Pakistan," Health Physics, Vol. 863, 2004, pp. 296-302.

doi:10.1097/00004032-200403000-00006

[4] D. R. Dreesen, J. M. Williams, M. L. Marple, E. S. Gladney and D. R. Perrin, "Mobility and Bioavailability of Uranium Mill Tailings Constituents," Environmental Science \& Technology, Vol. 16, No. 10, 1982, pp. 702-709. doi:10.1021/es00104a013

[5] R. W. Leggett, "The Behavior and Chemical Toxicity of Uranium in the Kidney: A Reassessment," Health Physics, Vol. 57, No. 3, 1989, pp. 365-383. doi:10.1097/00004032-198909000-00001

[6] C. K. McDonald-Taylor, M. K. Bhatnagar and A. Gilman, 
"Uranyl Nitrate-Induced Glomerular Basement Membrane Alterations in Rabbits: A Quantitative Analysis," Bulletin of Environmental Contamination and Toxicology, Vol. 48, No. 3, 1992, pp. 367-373. doi:10.1007/BF00195634

[7] S. C. Morris and A. F. Meinhold, "Probabilistic Risk Assessment of Nephrotoxic Effect of Uranium in Drinking Water," Health Physics, Vol. 69, No. 6, 1995, pp. 897908. doi:10.1097/00004032-199512000-00003

[8] A. P. Gilman, D. C. Villeneuve and V. E. Secours, "Uranyl Nitrate: 28-Day and 91-Day Toxicity Studies in the Sprague-Dawley Rat," Toxicological Sciences, Vol. 41, No. 1, 1998, pp. 117-128.

[9] P. Kurttio, A. Auvinen, L. Salonen, H. Saha, J. Pekkanen, I. Makelainen, S. B. Vaisanen, I. M. Penttila and H. Komulainen, "Renal Effects of Uranium in Drinking Water," Environmental Health Perspectives, Vol. 110, No. 1, 2002, pp. 337-342. doi:10.1289/ehp.02110337

[10] “Australian Drinking Water Guidelines," National Health and Medical Research Council, 1996.

[11] USEPA (US Environmental Protection Agency), "National Primary Drinking Water Regulations: Radionuclides; Final Rules," Federal Register, Vol. 65, No. 236, 2000, pp. 76708-76753.

[12] Health Canada, "Summary of Guidelines for Canadian Drinking Water Quality," Health Canada, Ottawa, 2002.

[13] WHO, "Guidelines for Drinking-Water Quality," 3rd Edition, World Health Organization, Geneva, 2003.

[14] R. L. Fleischer, P. B. Price and R. M. Walker, "Nuclear Tracks in Solids," University of California Press, Berkeley, 1975 , p. 489.

[15] A. A. Qureshi, N. U. Khattak, M. Sardar, M. Tufail, M. Akram, T. Iqbal and H. A. Khan, "Determination of Uranium Contents in Rock Samples from Kakul Phosphate Deposit Abbotabad Pakistan Using Fission Track Technique," Radiation Measurement, Vol. 34, No. 1, 2001, pp. 355-359. doi:10.1016/S1350-4487(01)00185-8

[16] K. Ullah, N. U. Khattak, A. A. Qureshi, M. Akram, H. A. Khan and A. Nisar, "Search for Uranium Source in Warcha Sandstone, Salt Range, Pakistan, Using SSNTD Technique," Radiation Measurements, Vol. 40, No. 2-6, 2005, pp. 491-495.

[17] M. Iqbal, S. Baig, N. U. Khattak, M. Akram, Z. Ahmad and A. A. Qureshi, "Fission-Track Uranium Determination, Geological Investigation and Health Hazards Related to Aggregates Used as Building Materials in Muzaffarabad, Azad Kashmir, Northwest Himalaya, Pakistan," European Journal of Scientific Research, Vol. 16, No. 3, 2007, pp. 405-411.

[18] M. Akram, N. U. Khattak, I. Ullah and M. Tufail, "Fission Track Estimation of Uranium Concentrations in Liquid Homeopathic Medicine Samples," Radiation Measurement, Vol. 43, 2008, pp. S527-S531. doi:10.1016/j.radmeas.2008.03.011

[19] A. I. Selden, C. Lundholm, B. Edlund, C. Hogdahl, B. M. Ek, B. E. Bergstrom and C. G. Ohlson, "Nephrotoxicity of Uranium in Drinking Water from Private Drilled Wells," Environmental Research, Vol. 109, No. 4, 2009, pp. 486-494. doi:10.1016/j.envres.2009.02.002
[20] F. Malik, Matiullah, M. Akram and U. Rajput, "Measurement of Natural Radioactivity in Sand Samples Collected along the Bank of Rivers Indus and Kabul in Northern Pakistan," Radiation Protection Dosimetry, Vol. 143, No. 1, 2011, pp. 97-105. doi:10.1093/rpd/ncq356

[21] S. N. Husaini, J. Zaidi, Matiullah and M. Akram, "Comprehensive Evaluation of the Effluents Eluted from Different Processes of the Textile Industry and Its Immobilization to Trim Down the Environmental Pollution," Journal of Radioanalytical and Nuclear Chemistry, Vol. 288, No. 3, 2011, pp. 903-910. doi:10.1007/s10967-011-1024-Z

[22] S. N. Husaini, J. Zaidi, Matiullah and M. Akram, "Evaluation of Toxic Metals in the Industrial Effluents and Their Segregation through Peanut Husk Fence for Pollution Abatement," Journal of Radioanalytical and Nuclear Chemistry, Vol. 289, No. 1, 2011, pp. 203-211. doi:10.1007/s10967-011-1062-6

[23] S. N. Husaini, J. H. Zaidi, Matiullah, M. Arif and M. Akram, "Evaluation of Toxicity Level of the Polluted Eco-System for an Industrial City of Pakistan," Journal of Radioanalytical and Nuclear Chemistry, Vol. 290, No. 2, 2011, pp. 459-468. doi:10.1007/s10967-011-1217-5

[24] S. N. Husaini, J. H. Zaidi, Matiullah, K. Naeem and M. Akram, "Metal Poisoning and Human Health Hazards Due to Contaminated Salad Vegetables," Journal of Radioanalytical and Nuclear Chemistry, Vol. 287, No. 2, 2011, pp. 543-550. doi:10.1007/s10967-010-0757-4

[25] S. K. Chakarvarti, N. Lal and K. K. Nagpaul, "Uranium Trace Analysis of Some Materials Using Solid State Nuclear Track Detectors. The Solid State Nuclear Track Detectors," Oxford Pergamon Press, Oxford, 1980, pp. 701715.

[26] A. Bansal, P. Rawat, J. Jojo and R. Prasad, "Analyzing Uranium Concentrations in Drinking Water Samples in India Using the Fission Track Technique," Health Physics, Vol. 62, No. 3, 1992, pp. 257-259. doi:10.1097/00004032-199203000-00008

[27] R. L. Fleischer and D. B. Lovett, "Uranium and Boron Content of Water by Particle Tracking Etching," Geochimica et Cosmochimica Acta, Vol. 32, No. 10, 1968, pp. 1126-1128. doi:10.1016/0016-7037(68)90112-9

[28] S. A. Durrani and R. K. Bull, "Solid State Nuclear Track Detection: Principles, Methods and Applications," Pergamon Press, Oxford, 1987.

[29] ICRP-30 (International Commission on Radiological Protection), "Limits for the Intake of Radionuclides by Workers," Pergamon Press, Oxford, 1979.

[30] WHO, "Guidelines for Drinking Water Quality; Addendum to Volume 2," World Health Organization, Geneva, 1998.

[31] EFSA, "Uranium in Foodstuffs, in Particular Mineral Water. Scientific Opinion of the Panel on Contaminants in the Food Chain," The European Food Safety Authority (EFSA) Journal, Vol. 1018, 2009, pp. 1-59.

[32] J. S. Drury, S. P. Reynolds, T. Owen, R. H. Ross and J. T. Ensminger, "EPA Report by Health and Environmental Studies Program," Oak Ridge National Laboratory, Oak Ridge, ORN1 Report No. EPA 570/9-81-001, 1981. 
[33] Province of British Columbia, "Variation in Uranium and Radioactivity Levels in Surface and Ground Water at Selected Sites in British Columbia April 1980-March 1981," B.C. Ministry of Energy Mines and Petroleum Resources and B.C. Ministry of Health Victoria, 1981.

[34] M. A. Moss, "Chronic Low Level Uranium Exposure via Drinking Water-Clinical Investigations in Nova Scotia,” M.Sc. Thesis Dalhousie University, Halifax, 1985.

[35] R. N. Betcher, M. Gascoyne and D. Brown, "Uranium in Ground Waters of Southeastern Manitoba, Canada," $\mathrm{Ca}$ nadian Journal of Earth Sciences, Vol. 25, 1988, pp. 20892103. doi:10.1139/e88-193

[36] S. K. Sahoo, S. Mohapatra, A. Chakrabarty, C. G. Sumesh,
V. N. Jha, R. M. Tripathi and V. D. Puranik, "Distribution of Uranium in Drinking Water and Associated AgeDependent Radiation Dose in India," Radiation Protection Dosimetry, Vol. 136, No. 2, 2009, pp. 108-113. doi:10.1093/rpd/ncp147

[37] ATSDR (Agency for Toxic Substances and Disease Registry), "Toxicological Profile for Uranium-An Update," US Department of Health and Human Services, Public Health Service, Atlanta, 2011.

[38] USGS, "History of the National Uranium Resource Evaluation. Hydrogeochemical and Stream Sediment Reconnaissance Program," US Geological Survey, 2006. 